\title{
Traditional Cross-Border Trade in Forest Products Between Indonesia and Malaysia: An Analytical Study of a Border Trade Agreement
}

\author{
Fajar Apriani ${ }^{1, *}$ Rahma Daniah $^{2}$ \\ ${ }^{1}$ Public Administration Department of Social and Political Sciences Faculty, Mulawarman University, Samarinda, \\ 75119, Indonesia \\ ${ }^{2}$ International Relations Department of Social and Political Sciences Faculty, Mulawarman University, Samarinda, \\ 75119, Indonesia \\ *Corresponding author. Email: yaniefajar@yahoo.com
}

\begin{abstract}
This research aims to analyze the traditional cross-border trade that has been established between Indonesian and Malaysian citizens around the border area before and after the introduction of the Border Trade Agreement (BTA), including reviewing some of the rules related to the BTA of Indonesia and Malaysia in 1970. This is deductivequalitative research by data collecting done by library research through literature review from scientific articles. This research focuses on trade in forest products at Indonesia-Malaysia's border areas and the sea border region's outer islands. The study results showed that although traditional trade has grown quite rapidly, both trade value and the type of goods traded, the border area is faced with many obstacles in developing its economic potential through trade activities to improve the welfare of the population. BTA and traditional trade can be combined as a form of crossborder trade between Indonesia and Malaysia with regulatory strengthening and a BTA review in 1970 to avoid dualism in trade in border areas and outer islands.
\end{abstract}

Keywords: Cross-border Trade, Border Trade Agreement, Forest Product, Economic Potential

\section{INTRODUCTION}

Indonesia and Malaysia are two countries that have direct borders, both land and sea. As a mutually adjacent area, the interaction between residents in both countries often occurs. One of them is the interaction in economic trade on the border between East Kalimantan and Sabah, Malaysia. This can be seen from traditional trade that has long occurred between communities on Indonesia and Malaysia's borders. The interaction behaviour of border communities in the two countries was triggered by the similarity of customs, ethnicity, and language. Socio-cultural similarities then led to the creation of traditional social and economic relations between them. These factors of similarity become the primary capital to make mutually beneficial interactions [1]. The high intensity and frequency of interaction between Indonesian and Malaysian citizens in the border region, especially in the economic field in traditional trade, is a serious concern by the governments of both countries.
Indonesia and Malaysia have similar aspirations and perceptions regarding the use of resources or the border area's potential to be managed for the two countries' border community' welfare and prosperity. To regulate the traffic of goods in traditional trade between border communities, the two governments also made agreements in the form of the Border Trade Agreement (BTA) or agreements on cross-border trade between the Indonesia Republic Government and Malaysia's Kingdom. BTA agreement was signed on August 24, 1970, in Jakarta. One of the agreement contents is the form of Malaysia-Indonesia Economic Social Cooperation or abbreviated as Sosek Malindo. Sosek Malindo's vision of cooperation is to improve the two regions' welfare through the Sosek Malindo collaboration towards 2020 [2].

The Sosek Malindo cooperation relationship at the regional level of East Kalimantan-Sabah, which began in 1995, is still going with several work programs that have been agreed upon to improve the people's welfare in two border regions. In its structure, Sosek Malindo is 
chaired by the General Border Committee (GBC) in each country. For Indonesia, it is led by the Indonesian National Army Commander as Chair of the GBC. Under the GBC structure, a Sosek Malindo working group has been established at the provincial level with the task of [3]: 1) determining the socio-economic development projects used together, 2) formulating matters relating to the implementation of socio-economic development in the border region, 3) carrying out information exchange on socio-economic development projects in the shared border area, 4) submitting reports to the central level Sosek Malindo working group on the implementation of socio-economic development cooperation in the border region.

Besides being coordinated by the Chairman of the Indonesian GBC, the Sosek Malindo working group also involved the Foreign Ministers of each country as Chair of the Joint Committee Meeting (JCM) and the Minister of Home Affairs to discuss bilateral cooperation and development of the Kalimantan border region between the Malaysian Government and the Indonesian Government [4]. In terms of trade in the border region between Indonesia and Malaysia, both the Border Crossing Agreement (BCA) and the BTA have expired and have not been reviewed. However, BCA in 2006 and BTA in 1970 was still used as references by Indonesia and Malaysia in inter-state trade activities because of the level of implementation. They had not shown any urgency for change, so that trade between Indonesia and Malaysia was still running in a corridor that both side parties could tolerate.

\section{RESEARCH METHODS}

This research is a qualitative descriptive study that explains the problem by analyzing data and information collection and reports the results. Bilateral cooperation in economics and trade focuses on observed micro phenomena while developing strategies and implementation focus on the macro phenomena being studied. Data collection for this study was carried out using literature and document studies as sources of research data. The type of data used is secondary data. Reference triangulation techniques do the validity and reliability of data testing. This research's analytical approach is a content analysis that explains and analyses data from research results that have been read and summarized from various written sources (document analysis). Data interpretation is then analyzed through deductive methods, which attempt to apply theories relevant to the phenomenon, formulate conclusions from data [5], and then present the study results.

\section{RESULT AND DISCUSSION}

\subsection{Border Area Development}

In the concept of development, five paradigms underlie the implementation process of action in a country, namely: 1) the growth paradigm, which emphasizes the trickledown effect and Rostowian growth theory, 2) the welfare state paradigm, which emphasizes redistribution with growth / basic need (Chenery), 3) the neo-economy paradigm, which emphasizes economics that emphasizes small people (Ul-Haq, Seer), 4) structuralize paradigm, which highlights the conditions of underdevelopment caused by economic structures (Frank, Dos Santos), and 5) humanizing paradigm, which emphasizes human insight (Goulet, Corten) [6].

To overcome poverty and underdevelopment in third world countries, several development strategies have been formulated: 1) development strategies oriented to growth or growth strategy, 2) development strategies to welfare or welfare strategy, and 3) development strategies people-centred development. In connection with the cooperation in the economy and trade fields in the border region between Indonesia and Malaysia, the three development strategies have contributed to analyzing this research's problem.

The growth strategy's weakness that makes development farther away from the community due to the gap between the rich and poor raises welfare strategy as a correction. A welfare-oriented development conception is an approach that, on the one hand, can be used to spur productivity, employment, and income. On the other hand, it can also reduce the negative consequences of income inequality and control of development assets [7]. However, welfare strategy contains weaknesses in increasing people's dependence on the bureaucracy, and the community must adjust to what the bureaucracy has given [8]. Then in the 1980s, there emerged a human-centred development strategy that contained two views, namely: 1) production centred development that places people as objects in development, 2) people/human-centred development that emphasizes the importance of human strengthening, namely human ability to actualize all its potential as human beings [6]. The people-centred development paradigm provides the best space for local initiatives and diversity and the importance of independent local communities, as stated in [8]. In connection with this matter, in the Indonesia-Malaysia border region's development process to improve the people's welfare, the Government has implemented a people-centred development strategy. Still, its benefits have not been optimally perceived by the people in the border area. 


\subsection{Conception of Indonesia-Malaysia Bilateral Cooperation in the Field of Economy and Trade in the Border Region}

International cooperation is one critical element in the implementation of foreign policy and politics. Through international collaboration, both bilaterally and multilaterally, Indonesia is expected to utilize various opportunities to support and carry out its national development [9]. Indonesia-Malaysia bilateral cooperation relationship is one of the international cooperation that needs to be maximized to capture the opportunities in the border region's development process based on a principle of mutual benefit continues to this day.

Indonesia has several border areas with neighbouring countries, both inland and sea (outer islands). Overall, the border region with neighbouring countries is spread in 12 provinces [10]. However, only four regions have land borders with other countries, namely West Kalimantan, East Kalimantan, East Nusa Tenggara, and Papua [11]. The borderline on the island of Kalimantan between Indonesia and Malaysia stretches throughout $2004 \mathrm{~km}$. The region has a strategic meaning, both in terms of security and economic, social, and cultural points of view. One of Indonesia's border regions with relatively high economic activity and interaction is the border between East Kalimantan and Sabah.

Since 1985 there has been the establishment of a social-economic cooperation forum at the level of West Kalimantan Province-Sarawak, and Sosek Malindo at the level of East Kalimantan Province in 1995 the scope of cooperation in the fields of social, economic, trade and infrastructure. For the East Kalimantan regional level socio-economic cooperation, the country is approved and signed on September 18-20, 1995, in Bandung. The process of forming the working group forum lasted for four years. Sosek Malindo Kalimantan Timur-Sabah cooperation was then officially inaugurated on September 4, 1996, in Kinibalu [12].

BCA and BTA are closely related even though they are different in the realm. BCA is related to regulating the cross-border movement of people, while BTA has to do with the cross-border movement of goods movements between countries. BCA, which was agreed between Indonesia and Malaysia on June 12, 2006, has expired in Bukit Tinggi, West Sumatera. Refers to Article 14 Paragraph 2 in BCA, it is stated that five years after the agreement has been reached, a review must be made. That is, in 2011, BCA in 2006 should have been reviewed. In fact, until 2018, a new BCA agreement has not been produced [10]. While for Indonesia-Malaysia, BTA is even worse. Since it was agreed on August 24, 1970, it has never been reviewed in Jakarta until now, so it has expired for 48 years.

\subsection{Traditional Cross-Border in the Indonesia- Malaysia Border Region}

Traditional cross-border trade has been established between Indonesian and Malaysian citizens around the border area before the BTA is implemented. In the dynamics of the development of Indonesian-Malaysian relations, in principle said by the Head of Economic and Business Development Division of the Border, Inland and Disadvantaged Areas Management Agency of East Kalimantan Province [13], there were no indications that this caused a change in BCA, except in the Indonesian position with the expansion of sub-districts in the border region. As well as the BTA in 1970, the indication of principle change lies in 1) determining the value of trade, 2) types of goods that can be traded, both qualitatively and quantitatively, and 3) the use of currency values and whether trading in sea border areas and islands the outermost border with other countries is still relevant to use BTA because Malaysia and the Philippines use barter trade which is a BIMP-EAGA agreement that is not subject to BTA rules. The BIMPEAGA agreement accommodates traditional forms of trade that have long been carried out in the East Kalimantan region in the North-Sabah-Southern part of the Philippines.

Concerning determining the value of cross-border trade, the trade value set at RM 600/person/month is insufficient because the same amount of money is measured based on purchasing power parity in both countries. This has caused a decrease in the number of goods purchased, while the demand for the number of goods remains or even increases [14]. Thus, indirectly the cross-border trade value is more than RM 600, in line with the rise in prices (inflation) in both countries. Therefore, it is necessary to determine the magnitude of the value of cross-border trade that is reasonable, which is agreed upon.

About the type of goods traded, based on the 1970 BTA, extractive commodities are more emphasized for Indonesia, while processed (manufacturing) commodities, including capital goods for small-scale industrial purposes, are more stressed for the Malaysian side. According to BTA, in 1970, cross-border trade products emphasized meeting basic needs for a decent living for the two countries' border regions. Economic development in both countries certainly has an impact on improving welfare. This results in a shift in the necessity of life, which increases to meet the living needs of primary goods and includes other secondary goods, especially in Indonesia. Such conditions certainly benefit Malaysia more because the reciprocal value of processed goods certainly gives greater added value than Indonesia's merchandise that relies on extractive commodities. But with lower prices, Indonesia's demand for extractive commodities by Malaysia continues to increase, especially for 
agricultural and fishery commodities used for industrial raw materials for Malaysia.

Traditional cross-border trade, although the area coverage is the same as BTA, which is the border region between countries, but does not refer to the limit of trade value according to BTA, so also the type of goods may not match the list of items agreed by both parties as stipulated in the BTA provisions. For example, wood does not apply as a product of trade or barter by the Indonesian side. On the contrary, Malaysia lists as tradable goods. Therefore, it is necessary to monitor the goods traded in the border/outermost islands so that these goods do not come out of the area and are considered illegal goods, which requires the Government to take legal action.

Trade regulated in the BTA is matched with traditional forms of trade (which Malaysia calls barter trade) due to a common principle regarding restrictions on trade areas' scope. With the ASEAN Economic Community formation, BTA needs to be modified by combining BTA rules with traditional cross-border trade [10]. Because the reality in the field shows that international trade activities continue to increase, but the data on the number of exports and imports are not known with certainty, collided with an unclear legal basis, the magnitude of the opportunities for illegal trade activities, especially in the sea border area due to a large number of in and out access and the extent of the area that is relatively difficult to monitor on an ongoing basis by the Government. The limitation of the scope of the area to be applied to trade must refer to the Indonesian Republic Law Number 43 of 2008 concerning the Territory of the Country and BCA Indonesia-Malaysia.

In the framework of this modification, the field of Economic and Business Development Division of the Border, Inland and Disadvantaged Areas Management Agency of East Kalimantan Province formulates that the types of goods that have been stipulated in the BTA rules are still used as a reference for goods that can be carried by residents holding cross-border passages or passports, which carry out cross-border movements between countries, are not subject to entry/exit charges. While other items, as long as they are not included in each country's negative list, can be categorized as commercial value merchandise [14].

A number of these restrictions are in line with the principle of prioritizing domestic production commensurate with the border region community's income level, which is eroded mainly by a relatively high burden of life.

Table 1. Comparison of Trade in Goods in BTA, Traditional Trade, and Cross-Border Free Trade

\begin{tabular}{|c|c|c|c|c|c|}
\hline \multirow[b]{2}{*}{ No } & \multirow{2}{*}{$\begin{array}{l}\text { Description } \\
\text { Differences }\end{array}$} & \multicolumn{3}{|l|}{ Type of Trade } & \multirow[b]{2}{*}{ Reference } \\
\hline & & BTA & Traditional Trade & $\begin{array}{l}\text { Cross-Border } \\
\text { Free Trade }\end{array}$ & \\
\hline 1 & Type of goods & Basic needs & $\begin{array}{l}\text { Basic needs and } \\
\text { others }\end{array}$ & $\begin{array}{l}\text { Basic needs, if }>\$ \\
400 \text {, subject to a } \\
\text { duty }\end{array}$ & $\begin{array}{l}\text { Law Number } 43 \\
\text { of } 2008 \text {, }\end{array}$ \\
\hline 2 & Value of goods & RM 600 & Not specified & $\begin{array}{l}\text { Limited in dollars } \\
\text { and duty-free }\end{array}$ & $\begin{array}{l}\text { Law Number } 26 \\
\text { of } 2007 \text {, }\end{array}$ \\
\hline 3 & $\begin{array}{l}\text { The imposition of } \\
\text { import duty }\end{array}$ & Free & $\begin{array}{l}\text { Charged, } \\
\text { including basic } \\
\text { necessities } \\
\text { >RM } 600\end{array}$ & $\begin{array}{l}\text { Charged if basic } \\
\text { necessities } \\
>\$ 600\end{array}$ & $\begin{array}{l}\text { Government } \\
\text { Regulation } \\
\text { Number } 26 \text { of } \\
2008 \text {, }\end{array}$ \\
\hline 4 & Utilization of sea lanes & $\begin{array}{l}\text { Use the boat as a } \\
\text { mode of } \\
\text { transportation } \\
\text { (sea) }\end{array}$ & $\begin{array}{l}\text { There is no } \\
\text { limitation on boat } \\
\text { load (sea) }\end{array}$ & $\begin{array}{l}\text { There is no } \\
\text { limitation on boat } \\
\text { load (sea), but } \\
\text { must be } \\
\text { registered }\end{array}$ & $\begin{array}{l}\text { Presidential } \\
\text { Regulation } \\
\text { Number } 78 \text { of } \\
2005 .\end{array}$ \\
\hline
\end{tabular}

Source: Diddy Rusdiansyah [13] 
Table 2. The Product of the Border Region of East Kalimantan which has the Potential to Become a Superior Product of Cross-Border Trade

\begin{tabular}{lr}
\hline Scope of Extraction Sector & Types of Products \\
\hline Agriculture (food crops, forestry plantations) & a. Food crops - Adan Krayan's rice \\
& b. Plantations - oil palm, rubber, pepper, cocoa, coffee, deep \\
& coconut, cloves, and cinnamon \\
& c. $\quad$ Forestry - wood and associated forest products such as resin, \\
& gaharu, rattan, forest honey and bird nests.
\end{tabular}

Farm

Cows, Krayan's buffaloes, and chickens (buras)

Fisheries

Land fisheries (ponds), marine fisheries (catches), and seaweed

Source : Diddy Rusdiansyah [14]

This is because the national logistics system's length and the distribution chain to the border/outermost islands have caused the price to be paid by the local people to be more expensive than the costs for the same goods from other countries that directly border with Indonesia. So, the border region community prefers to conduct trade activities now to obtain lower prices.

Border area, which is faced with many obstacles in its development efforts, has many economic potentials that can still be developed through trade activities to improve border communities' welfare. This form of cross-border trade can be a solution, namely combining BTA and traditional trade with the agreement on regulation through a BTA review in 1970 . There will be no dualism in trade in the Indonesia-Malaysia border region through legal certainty in controlling crossborder trade. In addition, the Government needs to develop local economic potential based on the use of local (extractive) natural resources that can be preeminent to encourage investment activities by business actors to create the welfare of the border region community.

Kalimantan forest, especially East Kalimantan, which borders directly with Sabah, is very rich in various biodiversity. Around $60 \%$ of all families and $36 \%$ of tree genera in Kalimantan are found in East Kalimantan forests, especially in the protected forest/national park area [15]. Most of the food in border communities is obtained from plants. Sago, which is usually obtained from four species, is the most essential and various tubers (Xanthosoma sp., Colocasia gigantea, Dioscorea pentaphylla, etc.) besides fruits and vegetables $[16,17]$. Even in the border river area, based on the latest surveys, including those conducted by CIFOR (Center for International Forestry Research), many fish species resources wealth [18].
In the present, extractive products (not including mineral mining), the border area's hallmarks in East Kalimantan, are still at the identification level, while the quantitative potential is not yet known with certainty. Extractive products that include agriculture, livestock, and fisheries have been identified to be further developed as superior products (see table 2). However, most of these products are available on a limited scale due to some causes, namely: 1) the potential use of the market is hampered by the limitations of transportation infrastructure (isolation of the region) in addition to inconsistent market demand, 2) lack of post-production maintenance and handling techniques especially for products those that do not have long-lasting durability, so that the level of productivity and quality of production has not been optimal, 3) not yet fully utilizing superior seeds, 4) financial support is relatively minimal, considering that rural economic institutions have not fully developed [19].

Most of the people in the border areas also apply shifting, hunting, and collecting forest products. The dependence on forests is still relatively high, with households near intact forests most dependent on forest products for livelihoods and daily consumption, especially in more remote villages [20,21]. The most agricultural-oriented group also highly valued natural resources and forests [17], although the degree of dependence differs significantly between each group and location [18]. This condition makes cross-border trade always increase due to the availability of natural resources and forests in the border area. The forest becomes very important for the local population.

\section{CONCLUSION}

The study results show that although international trade has developed quite rapidly, both the value of trade and the types of goods traded, the border area is faced with many obstacles to expanding its economic potential through trade activities to improve the welfare 
of the population. BTA and traditional trade can be combined as a cross-border trade between Indonesia and Malaysia with regulatory strengthening and a BTA review in 1970. There will be no dualism in the form of trade in the outer border islands. BTA and traditional cross-border trade cannot be equated because BTA only regulates certain types of goods, which are generally extractive goods from Indonesian parties, and from Malaysia in the form of goods processed by basic needs, including types of goods for industrial purposes small scale, along with determining the value of the trade. Whereas traditional cross-border trade, although the area coverage is the same as BTA, which is the border region between countries, but does not refer to the limit of trade value according to BTA, so also the type goods may not match the list of items agreed by both parties as stipulated in the BTA provisions. However, both forms of trade can be combined based on the principle of equality, namely the limitation of the scope of the trade area and based on the reality on the ground, which shows that traditional trade in the Indonesia-Malaysia border region has always been increasing, so that the review of the BTA is urgent to be carried out as legal certainty in controlling cross-border trade.

\section{REFERENCES}

[1] R. Siburian, Kondisi Perekonomian Masyarakat Perbatasan: Entikong dan Nunukan, Masyarakat Indonesia: Majalah Ilmu-ilmu Sosial Indonesia, LIPI, Jakarta, 30(2), 2004, p. 114.

[2] S. Sudiar, Sosek Malindo Kaltim-Sabah, Kerjasama Pembangunan Internasional di Wilayah Perbatasan Negara, Pustaka Radja, Surabaya, 2011, p. 42.

[3] D. Koespramoedyo et al, Strategi dan Model Pengembangan Wilayah Perbatasan Kalimantan, Bappenas, Direktorat Pengembangan Kawasan Khusus \& Tertinggal, Deputi Bidang Otonomi Daerah \& Pengembangan Regional, Jakarta, 2003, p. 27.

[4] S. Sudiar, op.cit, p. 43

[5] D. Silverman, Doing Qualitative Research, Sage, London, 2005, p. 6.

[6] M. Tjokroaminoto, Pembangunan Dilema dan Tantangan, Pustaka Pelajar, Jakarta, 1996.

[7] S.A. Wahab, Kebijakan Publik: Konsep dan Realita dalam Konteks Politik Indonesia, Gava Media, Yogyakarta, 2014

[8] D.C. Korten, Pembangunan Berdimensi Kerakyatan, Yayasan Obor, Jakarta, 1989.

[9] Departemen Luar Negeri Republik Indonesia, ASEAN Selayang Pandang, Direktorat Jenderal Kerjasama ASEAN, Jakarta, p. 1.
[10] Kementerian Perencanaan Pembangunan Nasional/Bappenas, RPJNM 2010-2014, Direktorat Kawasan Khusus dan Daerah Tertinggal, Jakarta, 2010, p 63.

[11] D. Koespramoedyo et al, op.cit, p. 1.

[12] S. Sudiar, op.cit, p. 5.

[13] D. Rusdiansyah, Perdagangan Lintas Batas Tradisional Indonesia-Malaysia, Buletin Kawasan Perbatasan Kalimantan Timur, Samarinda BPKP2DT, $1^{\text {st }}$ edition, 4, 2013, pp. 14-17.

[14] D. Rusdiansyah, Perlunya Perdagangan Lintas Batas Laut Dimasukkan dalam Revisi Border Trade Agreement (BTA) Tahun 1970 - Suatu Tinjauan Teoritis, 2013, http://diddyrusdiansyah.blogspot.com/2013/05 accessed at June 15, 2018

[15] Machfudh, General Description of the Bulungan Research Forest ed. CIFOR Forest, Science and Sustainability: The Bulungan Model Forest Technical Report Phase I 1997-2001, ITTO Project PD 12/97 Rev 1 (F) Bogor CIFOR, 2002.

[16] A. Uluk, M. Sudana, E. Wollenberg, Ketergantungan Masyarakat Dayak terhadap Hutan di Sekitar Taman Nasional Kayan Mentarang, CIFOR, Bogor, 2001.

[17] D. Sheil, et al, Exploring Biological Diversity, Environment and Local Peoples Perspective in Forest Landscapes $2^{\text {nd }}$ edition, CIFOR, Bogor, 2003.

[18] M. Ed. Moeliono, E. Wollenberg, G. Limberg, Desentralisasi Tata Kelola Hutan: Politik, Ekonomi dan Perjuangan untuk Menguasai Hutan di Kalimantan, CIFOR, Bogor, 2009.

[19] D. Rusdiansyah, Prospek Perdagangan Bebas Lintas Batas di Kawasan Perbatasan Kalimantan Timur - Malaysia Saat Ini dan Ke Depannya Berdasarkan Pendekatan Pragmatis, 2013, http://diddyrusdiansyah.blogspot.com/2013/02 accessed at June 17, 2018

[20] N. Anau, R. Iwan, M. van Heist, G. Limberg, M. Sudana, E. Wollenberg, Negotiating More Than Boundaries: Conflict, Power and Agreement Building in the Demarcation of Village Borders in Malinau, ed. CIFOR Forest, Science and Sustainability: The Bulungan Model Forest. Technical Report Phase I 1997-2001 ITTO Project PD 12/97 Rev 1 (F) Bogor CIFOR, 2002.

[21] P. Levang, Tim FPP-Bulungan, People Dependencies on Forests, ed. CIFOR, Forest, Science and Sustainability: The Bulungan Model Forest. Technical Report Phase I 1997- 2001, ITTO Project PD 12/97 Rev 1 (F) Bogor CIFOR, 2002. 